\title{
Kame or moraine? A sedimentological study of a glaciomarginal landform at Niedźwiedziny (Great Polish Lowland)
}

\author{
Aleksandra Ewert-Krzemieniewska \\ Institute of Geoecology and Geoinformation, Adam Mickiewicz University, Dzięgielowa 27, 61-680 Poznań, Poland; \\ e-mail: aew@amu.edu.pl
}

\begin{abstract}
A sedimentary succession in a gravel pit at Niedźwiedziny was investigated in order to determine its origin: kame or moraine. The gravel pit is located in an isolated hill of approx. $600 \mathrm{~m}$ long and $250-400 \mathrm{~m}$ wide.

The succession is built of glaciofluvial deposits: a sandy/gravelly unit in the lower and middle parts, overlain by diamicton. Five lithofacies have been distinguished, which represent two facies associations: (1) a fluvial association evolving from a high-energy to a transitional to a shallow braided river on an alluvial fan, and (2) an association of cohesive deposits representing a glacigenic mass flow. The interpretation is based mainly on palaeocurrent data and differs from conclusions by earlier investigators. The ice-marginal zone is characterised by a large variety of glaciomarginal forms. Their sedimentology, morphology and palaeogeography are determined by successive phases of deglaciation. The results of the present study show that the character of the deglaciation in the study area changed with time from frontal to areal deglaciation.
\end{abstract}

Keywords: sedimentology, glaciomarginal zone, kame, Weichselian, Middle Poland

\section{Introduction}

Both kames and end moraines commonly constitute glacial landforms with similar lithofacies, represented by alternating gravel and sand units, sometimes with till intercalations. Yet, they were formed under different conditions regarding the distance to the ice-sheet margin and the glacial palaeogeography. Kames usually occur as isolated and isometric hills, with an average size of several hundreds of metres and a height of up to $30 \mathrm{~m}$. They were formed by glaciofluvial processes in areas bordered by dead-ice masses. The most typical kames consist of fine-grained sands and silts of glaciolacustrine and/or glaciofluvial origin (Gruszka et al., 2012). As far as end moraines are concerned, they usually occur as ridges with differ- ent sizes. Usually moraines are arranged in a pattern connected with phases of ice-sheet stagnation. As a rule, the sediments that build moraines are badly sorted (from clay and silt up to gravels and boulders).

Previous studies (Krygowski et al., 1953-1961; Makowska, 1983; Sydow, 2004) indicated that the moraines in the western part of Gniezno Upland form two chains of hills (Fig. 1). This indicates that they must have originated close to two ice-sheet lobes. The sediments accumulated in front of both ice lobes indicate long-term ice-sheet stagnation and demarcate the boundary of the Poznań Phase marginal zone (Krygowski, 1953-1961; Kozarski, 1962), i.e. the second phase of the Main Stadial of the Weichselian, which is correlated with the Frankfurter Stadial in western Europe. It is worth- 


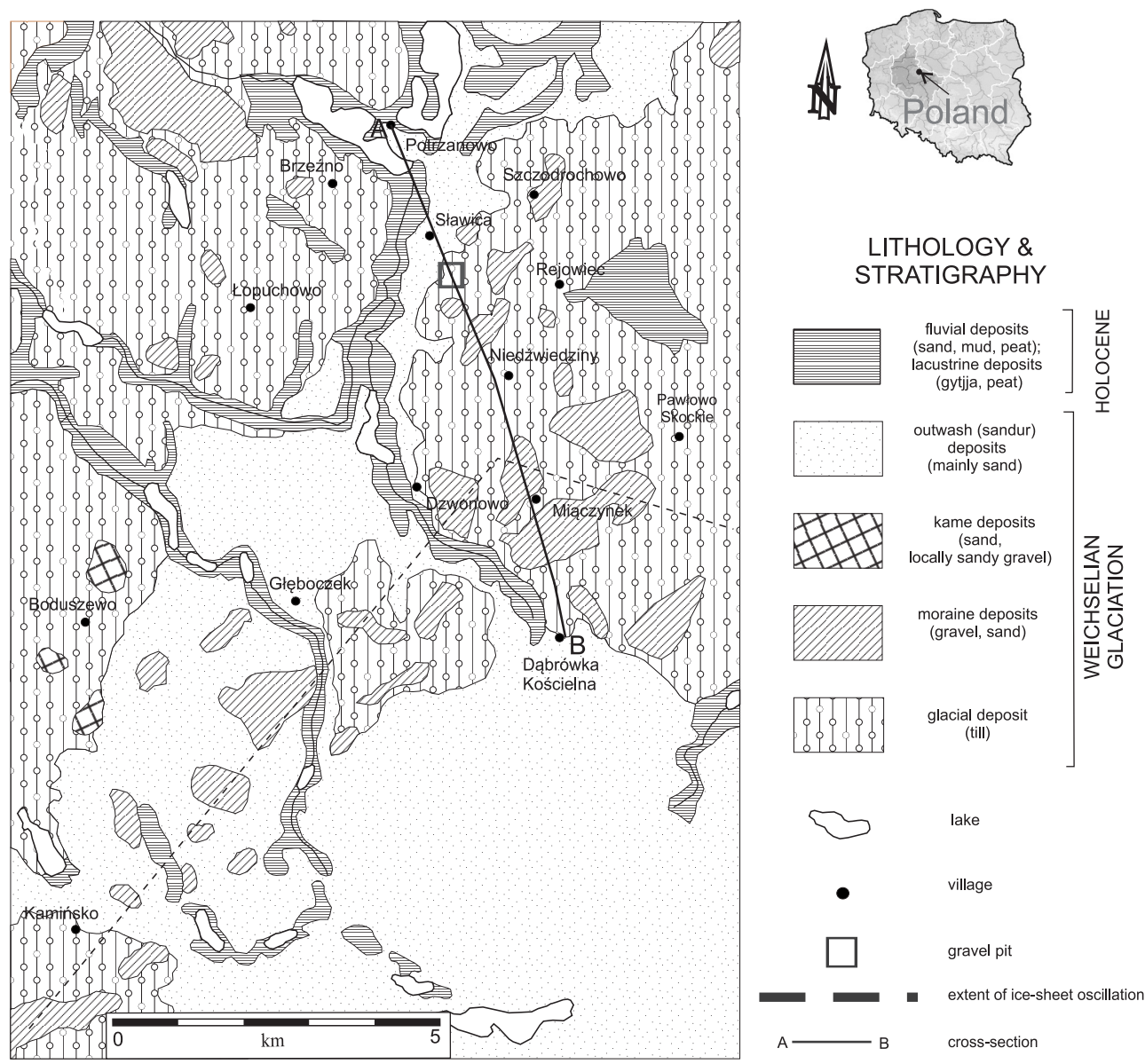

Fig. 1. Study area at Niedźwiedziny (eastern Great Polish Lowland) and distribution of Quaternary deposits on the Western Gniezno Upland (modified from Makowska, 1983)

while in this context to point out here that the study area is situated about $5 \mathrm{~km}$ further north, than the just-mentioned marginal zone. The landform under study here was regarded by Kozarski (1962) as a push moraine. The recently opened commercial gravel pit near Niedźwiedziny provided an opportunity to analyse the sedimentary succession in much greater detail.

The main objective of the present study is a lithofacies analysis of the Pleistocene glaciomarginal deposits in the Niedźwiedziny area (eastern Great Polish Lowland) in order to reconstruct the palaeogeography of the surrounding area, which might shed new light on the genesis of the hill, and which might clarify the character of the deglaciation after the Poznan Phase. A steadily retreating ice sheet would have left kames as records of areal deglaciation, whereas end moraines would be evidence of an ice-sheet retreat interrupted by some phases of re-advance (glacial oscillations).

\section{Geological and geomorphological setting}

The study area is located in the eastern part of the Great Polish Lowland, about $35 \mathrm{~km}$ north-east of Poznań, in the western Gniezno Upland (Fig. 1). The oldest Quaternary deposit at the surface of the area dates from the Poznan Phase of the Weichselian Glaciation (Fig. 2). It is a till, which extends over the whole Gniezno Upland (Fig. 1). Its thickness is up to $15 \mathrm{~m}$, but at the Niedźwiedziny site it reaches only about $2.5 \mathrm{~m}$. The undulating till plain is the basic geomorphological element surrounding the study area.

Some isolated, sandy-gravelly ridges occur in the study area. One of them is $15 \mathrm{~km}$ long, running NE-SW from Kamińsko to Dzwonowo; a second one, oriented NW-SE, starts at Dzwonowo, $30 \mathrm{~km}$ farther to east (Fig. 1). Sandur (outwash plain) de- 


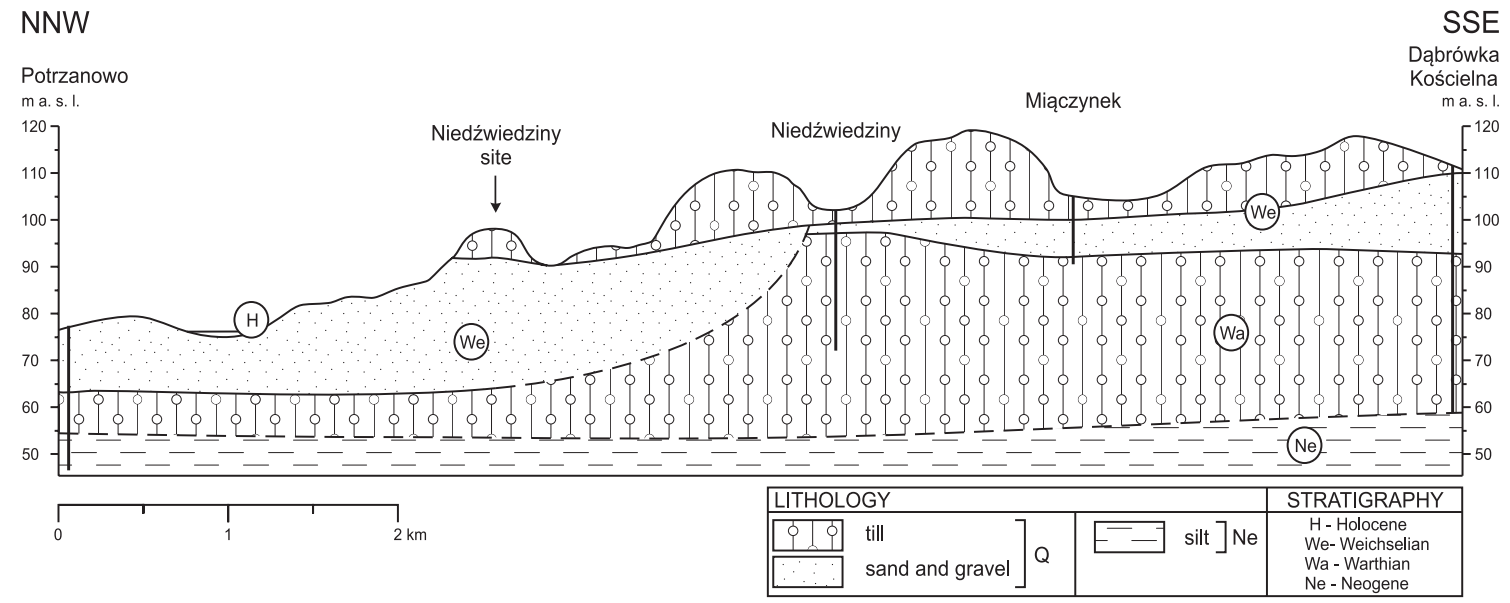

Fig. 2. Geological cross-section through the study area

posits, represented by sands and gravels are much more widely distributed over the study area (Fig. 1). As Kozarski (1962) noted, there are two sandur levels, which are associated with successive ice-sheet oscillations. Both of them form a low-relief plain, comprising an elongated zone of 2-14 $\mathrm{km}$ wide. A small kame field is located north and south-west of Boduszewo (Fig. 1). The kames are rounded, equidimensional forms, consisting of glaciofluvial silts and sands, locally with some gravels. The thickness of the kame sediments is from 5 up to $15 \mathrm{~m}$ (Sydow, 2004). The youngest deposits accumulated during the Holocene in valleys as well as in glacial channels. They consist of fluvial sands, silts and peats. Peat and gyttja were deposited simultaneously in the lacustrine depressions (Fig. 1).

The Niedźwiedziny site is situated in the NE part of the study area. It is a hill of about $25 \mathrm{~m}$ high, surrounded by till plain (Makowska, 1983) (Fig. 1). The hill is built of up to 20-23 m of glaciofluvial deposits, and of till in the upper part (Fig. 2).

\section{Methods}

Fieldwork was carried out to study the sedimentary successions of the hill in detail, so as to distinguish layers with similar granulometric and textural characteristics; combinations of some types of such layers have been grouped into lithofacies, each representing a sedimentary subenvironment. The lithofacies have been grouped into five lithofacies associations, each of which represents a different sedimentary environment.

The various types of layers and lithofacies are indicated in the text and figures by the letter codes proposed by Miall (1977) and adapted by Zieliński \& Pisarska-Jamroży (2012) (Table 1). The first code letter describes the main grain size, and codes between parentheses indicate grain sizes of secondary importance.

The thicknesses of depositional units are indicated as follows: small-scale $=2-10 \mathrm{~cm}$, medium $=10-20 \mathrm{~cm}$ and large $=>20 \mathrm{~cm}$. Dip directions of cross-laminae have been measured to reconstruct palaeocurrent directions. The Digital Elevation Model (DEM) of the relief around the Niedźwiedziny site was prepared as a desk study.

Table 1. Lithofacies codes used in the present study (after Miall, 1977; modified by Zieliński \& Pisarska-Jamroży (2012)

\begin{tabular}{cl}
\hline & \multicolumn{1}{c}{ Textural symbols } \\
\hline$D$ & diamicton \\
\hline$G$ & gravel \\
\hline$S$ & sandy gravel \\
\hline$S G$ & sand \\
\hline$S T$ & gravelly sand \\
\hline$T$ & silty sand \\
\hline$M$ & mud \\
\hline & $\quad$ Structural symbols \\
\hline$m$ & massive structure \\
\hline$h$ & horizontal lamination (stratification) \\
\hline$w$ & wavy stratification \\
\hline$r$ & ripple cross-lamination \\
\hline$r C$ & climbing ripple cross-lamination \\
\hline$l$ & low-angle cross-stratification \\
\hline$p$ & planar cross-stratification \\
$t$ & trough cross-stratification \\
\hline$d$ & deformed structure \\
\hline
\end{tabular}




\section{Description and interpretation of the lithofacies associations}

The succession under study is $20-25 \mathrm{~m}$ thick and is mainly composed of sand and gravel. A massive diamicton is present in the uppermost part of the excavation. Five lithofacies associations have been distinguished (Fig. 3): (a) as the lowermost association (1) gravelly channel deposits (GC), (b) in the middle part alternating associations of (2) sandy abandoned-channel deposits (SSC), (3) sandy shallow channel deposits (CSC), (4) sandy deep channel deposits (SDC) and (c) a topmost association of (5) glacigenic deposits $(\mathrm{G})$.

\subsection{Lithofacies association GC}

\subsubsection{Description}

The lowermost association (GC) is a 5-9 $\mathrm{m}$ thick coarse-grained succession consisting of two main lithofacies: GSp,(GSm) and GSh,(GSt) (Figs 3, 4). The association is dominated by sandy gravel with high-angle, planar cross-stratification (GSp) in sets of up to $0.6 \mathrm{~m}$ thick (Fig. 5A). The cross-bedding indicates current directions of some $280^{\circ}$. The GSp layers locally pass into massive layers (GSm), with beds up to $30 \mathrm{~cm}$ thick.

Lithofacies GSh,GSt consists of medium-scale, horizontally stratified sandy gravel, mostly matrix-supported GSh, with laterally co-occurring trough cross-stratified sandy gravel GSt (Figs 4, 5C). The GSh beds are 0.7-1.3 m thick, whereas the GSt layers are $0.7-1.0 \mathrm{~m}$ thick, with troughs up to $40 \mathrm{~cm}$.

\subsubsection{Interpretation}

Lithofacies GSp represents mid-channel transverse bars formed during falling stages. They formed in aggrading channel zones by prograding fronts of foreset bars (cf. Singh \& Bhardwaj, 1991; Santos \& Stevaux, 2000). The dominating gravel fraction points at intensive, highly-concentrated currents, operating during a waning stage. The associated massive, matrix-supported GSm layers originated in deeper parts of the channels, during phases of extensive discharge, from high-energy traction carpets, i.e. as high-concentration bedload layers (cf. Sohn, 1997). In the shallow channel zones, accumulation from supercritical currents under upper plane-bed conditions took place. Under these conditions sandy gravel sheets (GSh) developed.

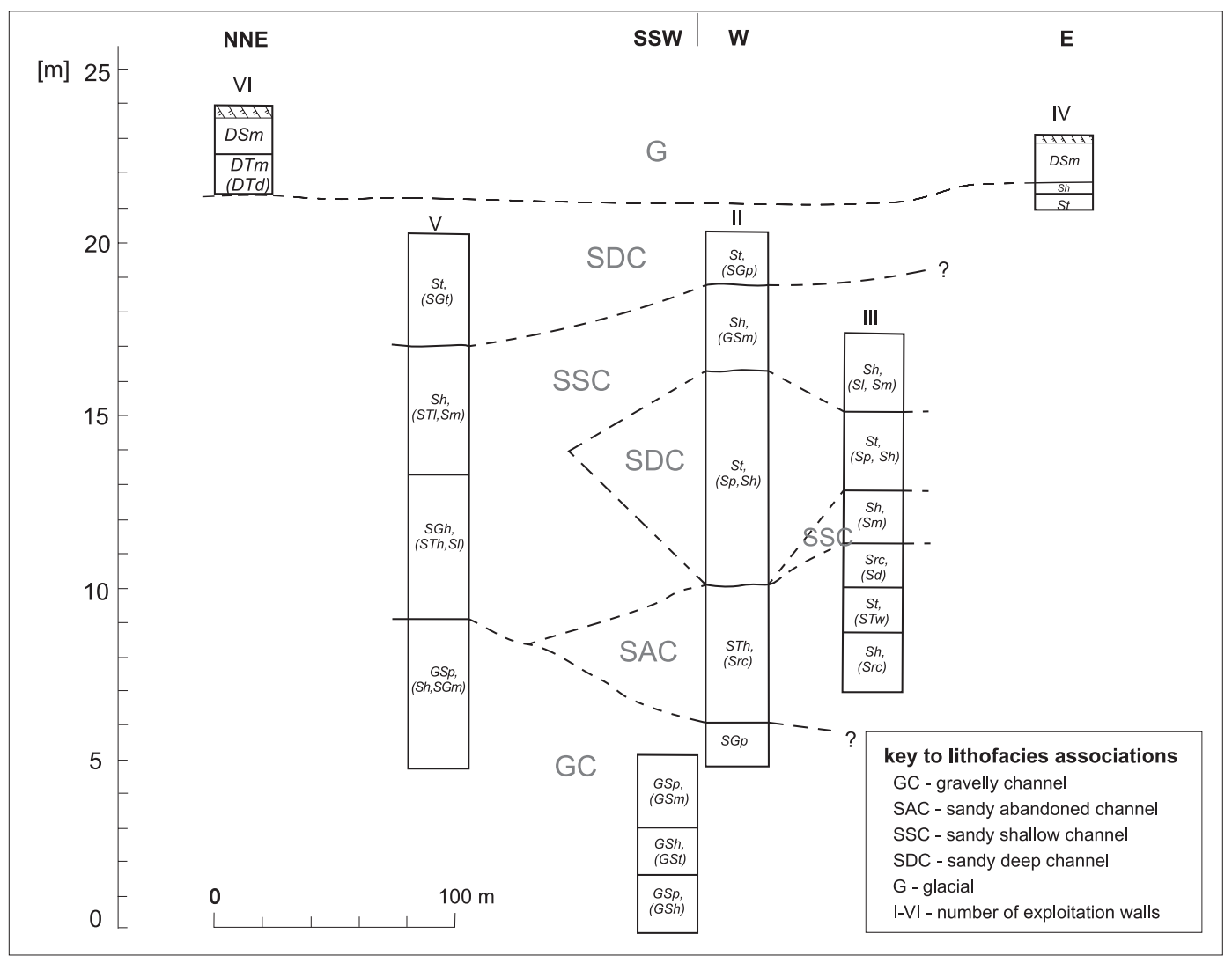

Fig. 3. Lateral extent of the lithofacies and lithofacies associations at Niedźwiedziny 


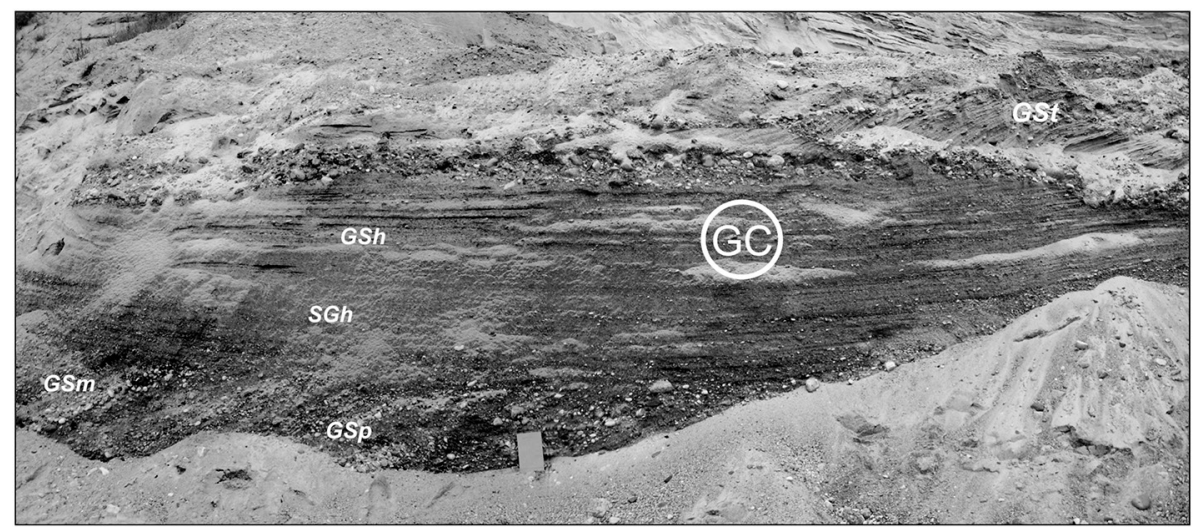

Fig. 4. Lithofacies of the gravelly channel association (GC)

They usually override the transverse bars GSp,(GSm) (Figs 4, 5C) (Cant \& Walker, 1978).

Lithofacies GSt and SGt are interpreted as representing the following sequence of sedimentation conditions. Gravelly/sandy cosets with trough cross-stratification developed in deep channels. The bottom became scoured and was afterwards filled with cross-stratified sediments supplied by gravelly-sandy 3-D dunes (cf. Jones et al., 2001; Marren, 2001). These troughs developed in inter-bar zones in the central parts of braided channels, where the intensity of the currents was highest. Considering the predomination of coarse-grained material in this association, it is inferred that the sedimentation took place in a gravel-bed braided-river environment characterised by highly unstable hydrodynamic conditions. Most probably, the braided river ran on the proximal part of a large alluvial fan (outwash plain) (Table 2); this is suggested by the lithological features of the association, which are quite similar to the $\mathrm{P}-2 \mathrm{~b}$ lithotype of $\mathrm{a}$ fan-derived succession (Zieliński, 1992).

\subsection{Lithofacies association SAC}

\subsubsection{Description}

The contact between the GC and the SAC association is sharp (Fig. 5E). The thickness of the complex does not exceed $5 \mathrm{~m}$. The SAC association consists of three fine-grained lithofacies: $S T h,(S r c), S t,(S T w)$ and $S r c,(S d)$ (Fig. 3).

The first facies is built of large-scale (approx. $1 \mathrm{~m}$ thick) horizontally stratified silty sand (STh) which is intercalated with climbing-ripple cross-laminated sand $(S r c)$ in cosets of up to $20 \mathrm{~cm}$ thick. Measure- ments of the cross-lamination in Src beds indicate that the laminae dip most commonly toward $210^{\circ}$ (Fig. 6).

The second facies contains abundant trough cross-stratified sand (St), alternating with wavylaminated silty sand (STw) of $10-20 \mathrm{~cm}$ thick. The thickness of the $S t$ cosets is up to $80 \mathrm{~cm}$. At the top of the SAC association, medium-scale, climbing-ripple cross-laminated sands with locally deformed structures, $S r c,(S d)$, occur. Thin (up to $10 \mathrm{~cm}$ ) massive silt beds $(T m)$ are also present.

\subsubsection{Interpretation}

The majority of the lithofacies constituting the SAC association indicate that the sediments were deposited in a shallow, low-energy fluvial environment. Fine-grained lithofacies are characteristic. Horizontally stratified silty sands (STh) represent quiet current conditions of the upper plane-bed flow regime. Frequent phases of low-discharge and even standing water are recorded as wavy-laminated fine-grained silty sands (STw) and sands with climbing ripples $(\mathrm{Src})$. The massive silt $(\mathrm{Tm})$ originated in stagnant water by suspension settling. The $S t$ beds are common in a deep-channel environment, but the trough cross-stratified sands $(S t)$ that alternate with wavy-laminated silty sand beds (STw) indicate short-lived pulses of ablational discharge.

The succession is interpreted as a deposit on an alluvial fan of a low-energy, relatively shallow sand-bed abandoned channel of low sinuosity lacking large floods (cf. Salamon \& Zieliński, 2010). The lithological characteristics of this lithofacies association show similarities to the D-5 lithotype of Zieliński (1992), which presents the middle or distal zone of an outwash plain (Table 2). 

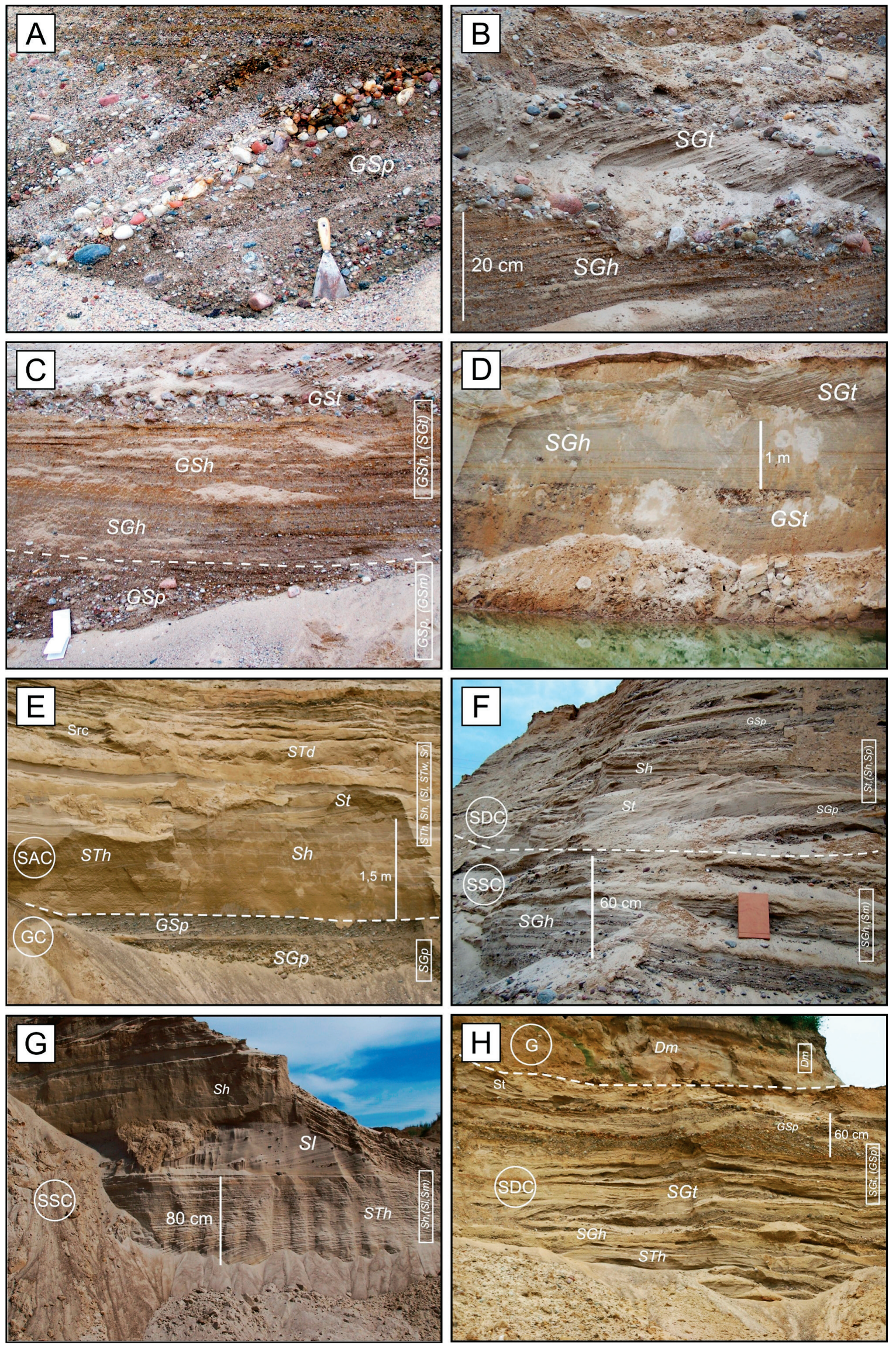
Fig. 5. Details of the succession

A: Sandy gravel with high-angle, planar cross-stratification (GSp); B: Horizontally-stratified gravelly sand (SGh) overlain by trough cross-stratified gravelly sand (SGt); C: Superimposed lithofacies GSp,(GSm) and GSh,(SGt); D: Layers in the north-eastern part of the pit: sandy gravel and gravelly sand with trough cross-stratification GSt and SGt intercalated by large-scale horizontally stratified gravelly sands; E: The gravelly channel association (GC) overlain by the fine-grained sandy abandoned-channel association (SAC); F: Middle part of the glaciofluvial succession, showing the sandy shallow-channel association (SSC) and the overlying sandy deep-channel association (SDC); G: Lithofacies $\mathrm{Sh},(\mathrm{Sl}, \mathrm{Sm})$ of the sandy shallow-channel complex (SSC); H: The uppermost glaciofluvial sandy deep-channel complex (SDC) with the glacial diamicton $(\mathrm{G})$ atop

\subsection{Lithofacies association SSC}

\subsubsection{Description}

The SSC lithofacies association is present at two levels in the succession (Fig. 4). Firstly, it overlies the fine-grained sandy abandoned-channel association (SAC), where it is represented by medium-scale sandy and sandy/gravelly layers with a rhythmic succession of horizontal and massive structures, $\mathrm{Sh}(\mathrm{Sm})$ (Fig. 3). Medium- and coarse-grained sands dominate here. In massive beds, a normal grain-size distribution is observed (Fig. 6). The thickness of the association at this place in the vertical succession is up to $2 \mathrm{~m}$.

Secondly, the same sandy shallow-channel association, though much thicker (up to $7 \mathrm{~m}$ ) developed, occurs in the uppermost part of the succession (Figs 5G, 6). It is represented by two main lithofacies, viz. SGh, $(S T h, S l)$ and $S h,(S l, S m)$ (Fig. 4). Coarse-grained sands with horizontal stratification $(S G h)$, alternating with sands with low-angle cross-stratification $(S l)$ dominate. The thickness of the $S G h$ cosets is up to $80 \mathrm{~cm}$, whereas the $S l$ intercalations are thinner, up to $40 \mathrm{~cm}$. It is characteristic that sandy and sandy/gravelly beds pass upwards into silty ones.

The sand beds with low-angle cross-stratification $(S l)$ dip mostly towards SW. Secondary lithofacies are massive, matrix-supported coarse sands, locally silty sands (Sm, STm), with beds of 20-40 cm thick.

\subsubsection{Interpretation}

The SSC lithofacies association accumulated in shallow, extensive streams under transitional and supercritical flow conditions, with frequent fluctu-

Table 2. Lithology and environmental interpretation of the lithofacies associations at Niedźwiedziny

\begin{tabular}{|c|c|c|c|}
\hline $\begin{array}{l}\text { Lithofacies } \\
\text { association }\end{array}$ & $\begin{array}{l}\text { Most } \\
\text { common } \\
\text { sediments }\end{array}$ & Architectural elements & Sedimentary processes/environment \\
\hline $\begin{array}{l}\text { glacial associa- } \\
\text { tion [G] }\end{array}$ & $\begin{array}{l}\text { DTm } \\
\text { DSm }\end{array}$ & GL glacial deposit (flowtill) & $\begin{array}{l}\text { mass flow redeposition (debris flow) } \\
\text { of supraglacial material to the area in front } \\
\text { of the ice-sheet; limited ablation during final } \\
\text { phase of glaciomarginal sedimentation }\end{array}$ \\
\hline $\begin{array}{l}\text { sandy } \\
\text { deep-channel } \\
\text { association } \\
\text { [SDC] }\end{array}$ & $\begin{array}{l}\text { St, SGt } \\
\text { SGp, Sh }\end{array}$ & $\begin{array}{l}\text { MR 3-D dunes } \\
\text { CF channel fill } \\
\text { FM foreset bars (transverse bars) } \\
\text { SU sandy upper plane bed }\end{array}$ & $\begin{array}{l}\text { main channel of braided fluvial system; } \\
\text { middle outwash plain }\end{array}$ \\
\hline $\begin{array}{l}\text { sandy shal- } \\
\text { low-channel } \\
\text { association } \\
\text { [SSC] }\end{array}$ & $\begin{array}{l}\text { Sl } \\
\text { SGh, Sm }\end{array}$ & $\begin{array}{l}\text { MR sandy wash-out dunes } \\
\text { SF scour fills } \\
\text { SU sandy/gravelly upper plane bed }\end{array}$ & $\begin{array}{l}\text { secondary channels of braided fluvial system; } \\
\text { middle outwash plain }\end{array}$ \\
\hline $\begin{array}{l}\text { sandy aban- } \\
\text { doned-channel } \\
\text { association } \\
\text { [SAC] }\end{array}$ & $\begin{array}{l}\text { STh } \\
\text { STw,Tm } \\
\text { Src }\end{array}$ & $\begin{array}{l}\text { SU sandy upper plane bed } \\
\text { SS fine suspension settling } \\
\text { RM climbing ripples }\end{array}$ & $\begin{array}{l}\text { abandoned secondary channels of braided } \\
\text { fluvial system; middle outwash plain }\end{array}$ \\
\hline $\begin{array}{l}\text { gravelly chan- } \\
\text { nel association } \\
{[G C]}\end{array}$ & $\begin{array}{l}\text { GSp } \\
\text { GSm } \\
\text { GSh } \\
\text { GSt }\end{array}$ & $\begin{array}{l}\text { FM gravelly/sandy foreset bars } \\
\text { (transverse bars) } \\
\text { HF hyperconcentrated flow } \\
\text { GS gravelly/sandy sheets } \\
\text { MR gravelly/sandy 3-D dunes }\end{array}$ & $\begin{array}{l}\text { proximal outwash plain with channelized } \\
\text { currents and sheet-like currents }\end{array}$ \\
\hline
\end{tabular}




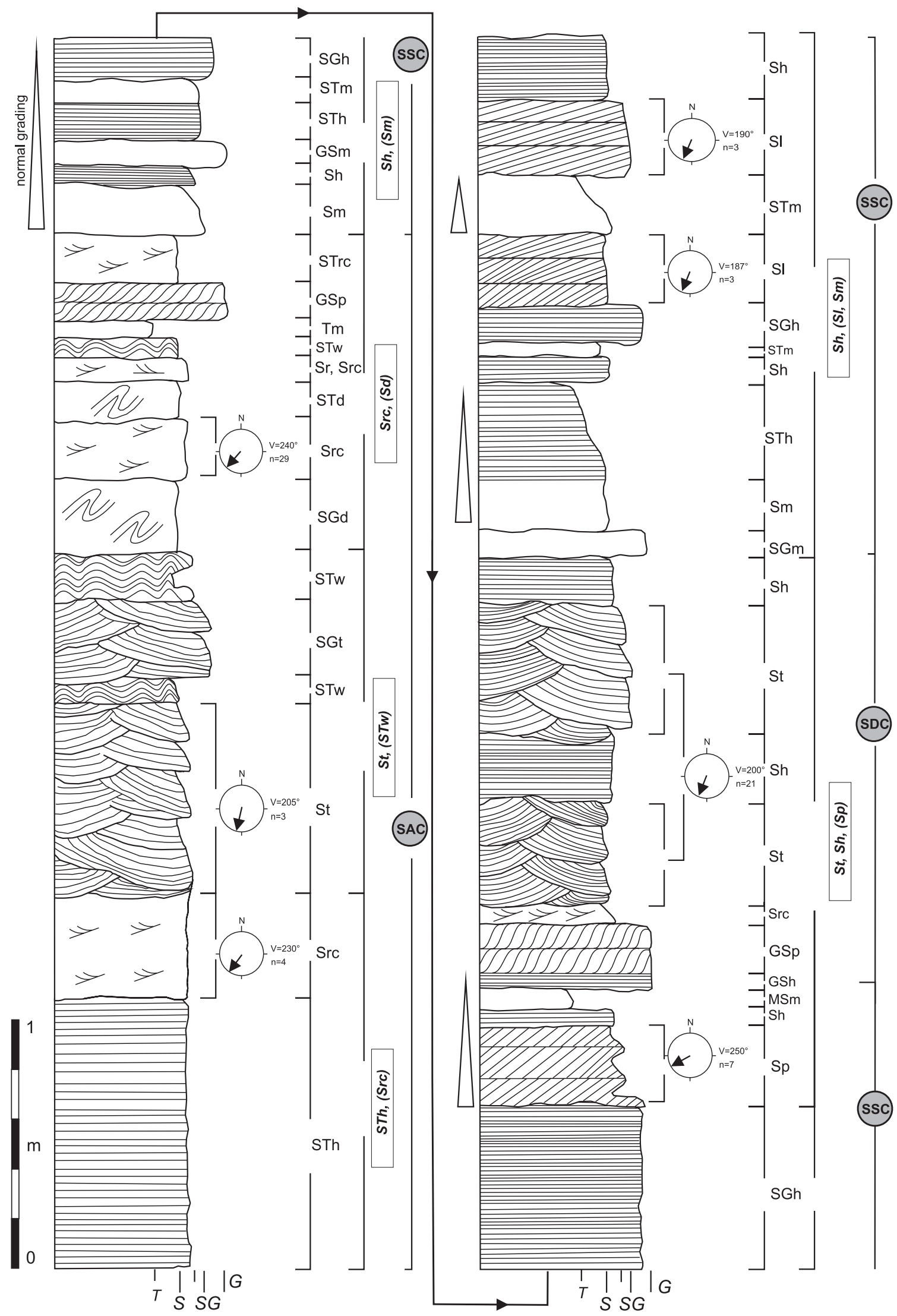

Fig. 6. Sedimentological log of the lithofacies associations in the middle part of the succession. Palaeocurrent directions are indicated. Symbols concerning the rose diagrams: $\mathrm{V}=$ mean current direction; $\mathrm{n}=$ number of measurements 
ations of the discharge. This resulted in a rhythmic arrangement of sandy and sandy/gravelly beds with horizontal lamination or a massive structure $(S h, S m)$, which were deposited under upper plane-bed conditions. The coarse fraction $(>40 \mathrm{~mm})$ at the base of the massive beds indicates that each sedimentary pulse started from traction-carpet deposition in powerful, rapid streams. Similar findings have been described by Todd (1989) and Hjellbakk (1997).

The upper gravelly sand horizontally stratified (SGh) beds possibly accumulated in lower-energy currents during a waning flood. The currents were unchannelised and probably were sheetfloods. Sedimentation of the $S h, S m$ facies took place in shallow meltwater streams, probably representing marginal parts of a braided outwash system.

In the upper part of the excavation, the lithofacies of the SSC as association represent a fluvial series of shallow, high-energy currents, comparable to sheet-like currents. The most abundant sediment types of this association ( $S G h$ and $S l$ ) support this interpretation. They were deposited under upper-stage plane bed (SGh) conditions, representing scour fills and low-relief, washed-out dunes ( $S l)$. Following Cowan (1991), they result from transitional to upper flow-regime conditions. Deposition took place in relatively shallow channels (thickness of cross-beds $<0.5 \mathrm{~m}$ ) in the middle of an alluvial fan (outwash plain). The fining-upward couples $(S h)$, as well as the thin massive silty sand beds (STm) indicate cyclic shoaling and recurring phases of standing water (Miall, 1996).

Taking all this together, the SSC lithofacies association must represent a shallow braided-river environment with strongly fluctuating energy conditions (Table 2).

\subsection{Lithofacies association SDC}

\subsubsection{Description}

The SDC lithofacies association occurs twice in the section under study (Fig. 3, 6). In the middle of the succession, the association most common sediment type is trough cross-stratified sand $(S t)$, which occurs in sets up to $40 \mathrm{~cm}$ thick and fining upward cosets up to $1.5 \mathrm{~m}$ thick. The cross-laminae dip towards $200^{\circ}$.

Beds of normally graded, planar cross-stratified sand $(S p)$ and horizontally stratified $(S h)$ sand are less common. The foresets of $S p$ beds dip toward the WSW. The horizontally stratified Sh beds are locally accompanied by thin beds of massive sandy mud $(\mathrm{MSm})$ and climbing-ripple cross-laminated sand $(S r c)$.
The uppermost part of the SDC association is, as far as visible, 1.5-2.5 m thick, but initial thickness, but may have reached $5 \mathrm{~m}$ before exploitation started (Fig. 6).

The main lithofacies are large-scale trough cross-stratified sands and gravelly sands $S t,(S G t)$ in cosets up to $1 \mathrm{~m}$ thick. Large-scale, planar cross-stratified gravelly sands $(S G p)$ are also frequent. These two types of layers occur jointly with beds of secondary frequency: horizontally stratified silty sands (STh) (in the lower part of the facies) and gravelly sands (SGh) (in the upper part). The thickness of the beds varies from $20 \mathrm{~cm}$ in the SE part of the excavation to $60 \mathrm{~cm}$ in the NW part.

\subsubsection{Interpretation}

The St beds represent migration of 3-D dunes, a typical bedforms of deep, high-discharge currents. The flood stages were interrupted by stages of average discharge, when sandy transverse bars ( $S p$ sediments) were formed. In the shallower zones, upper plane-bed lamination developed in mostly fast currents (origin of the Sh lithofacies). The massive sandy muds (MSm) and the climbing-ripple cross-laminated sands $(S r c)$ are interpreted as deposits accumulated in the abandoned channels of a braided system, when the activity of the currents had temporarily decreased (cf. Fielding \& Webb, 1996; Therrien, 2006). In the upper part of the SDC lithofacies association, the St, (SGt) beds are also associated with extensive and deep currents, which formed channel fills and sandy/ gravelly 3D dunes in the interbar channels. The SGp beds reflect coarse-grained transverse bars representing channel zones with a lower current energy.

The less common SGh beds indicate the presence of local plane-bed shoals, whereas and the STh beds represent near-bank zones with quiet currents.

As an entity, this lithofacies association is interpreted to reflect dynamic, high-energy sedimentation of a main channel of a sand-bed braided-river system (Table 2).

\subsection{Lithofacies association $\mathrm{G}$}

\subsubsection{Description}

The glaciofluvial succession is overlain by a diamicton $(\mathrm{G})$ (Figs 3, 5H, 7A). The lithofacies contain massive silty diamicton, locally deformed $D T m,(D T d)$ in the lower part of the association and massive, pseudolaminated sandy diamicton (DSm) in the upper part. The thickness of the association varies from 1 to $3.5 \mathrm{~m}$. The lower DTm(DTd) facies 
consists of a matrix-supported, massive silty diamicton, which passes vertically into a deformed diamicton of the same texture (Figs 7A, B). The deformed layer has an irregular thickness varying from 20 to $60 \mathrm{~cm}$ (Fig. 7B). Small, continuous deformations such as folds with variable orientations and symmetry are present. In the upper part of the diamicton, floating boulders of up to $15 \mathrm{~cm}$ occur in the $D S m$ facies. Thick angular DTm clasts of up to $1 \mathrm{~m}$ are also present in the DSm facies (Fig. 7B). Furthermore, a gradational, undulating contact is present between the DTm,(DTd) facies and the pseudolaminated massive sandy DSm facies (Fig. 7A).

\subsubsection{Interpretation}

The $\mathrm{G}$ lithofacies association was formed during an advanced phase of deglaciation, when glaciofluvial deposition had come to an end. The diamicton consists of glacial material which underwent reworking in the form of a mass flow (flow till). Its genesis is proven by its textural and structural features: a relatively small thickness, a lenticular shape, clusters of cobbles and boulders, a gradual transition between a massive and a pseudolaminated structure (cf. Ruszczyńska-Szenajch, 1998; Thomas \& Chiverrell, 2007; Sarala et al., 2009). The large amount of silt and clay indicates that the material slid down as a cohesive debris flow.

Deposition of the glacial $\mathrm{G}$ association took place during two phases. Initially, it acted as a mudflow (deposition of DTm), a fine-grained flow transported in a ductile/plastic way. The next phase was a mass flow of coarser material (DSm), deposited on the surface of the silty DTm diamicton. The silty material of the latter became incorporated in the most basal part of the more sandy mass flow; the best developed deformations occur therefore in the middle part of the diamicton.
Fluvial reworking did not take place after deposition of the flow tills. This indicates that the $G$ lithofacies association represents the final phase of glaciomarginal sedimentation. It suggests that deposition may have taken place in an interlobate area with dead-ice bodies, under low-discharge conditions.

\section{Palaeocurrent data}

Over 170 palaeocurrent measurements of cross-lamination and cross-stratification in both coarse- and fine-grained beds were obtained from six locations in the walls under study (Fig. 8). Those from glaciofluvial sediments at sites I, II and III show a mean direction toward the SW. The measurements at sites IV and V show a main current direction toward the SSW.

It should be mentioned, however, that the palaeocurrent pattern format site $\mathrm{V}$ shows significant variations of the current directions. There are two opposite main directions, which is typical for antidunes (cf. Saunderson, 1981; Fredsøe, 1982; Alexander et al., 2001). Taking this into consideration, it is possible that it was the environment of a shallow palaeochannel of the river system, with supercritical currents, where antidunes migrated upstream. It is alleged that the main palaeocurrent direction was towards the south, while the migration of antidunes took place toward the north (Fig. 8, wall V).

\section{Discussion}

Several aspects need some further discussion. They all concern the sedimentological genesis of the landform under study. The main aspects that
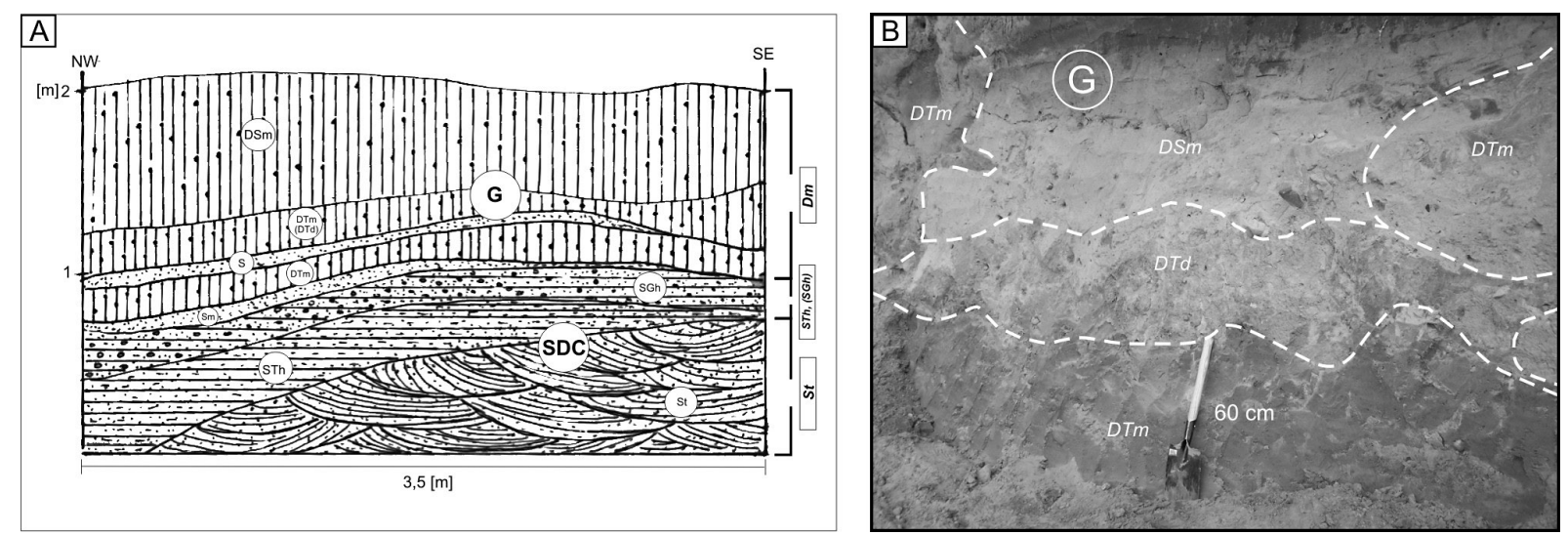

Fig. 7. Glacigenic association (G)

A: Contact between the upper glaciofluvial association (SDC) and the overlying diamicton (G); B: Types of deposits forming part of the glacigenic association $(\mathrm{G})$ 


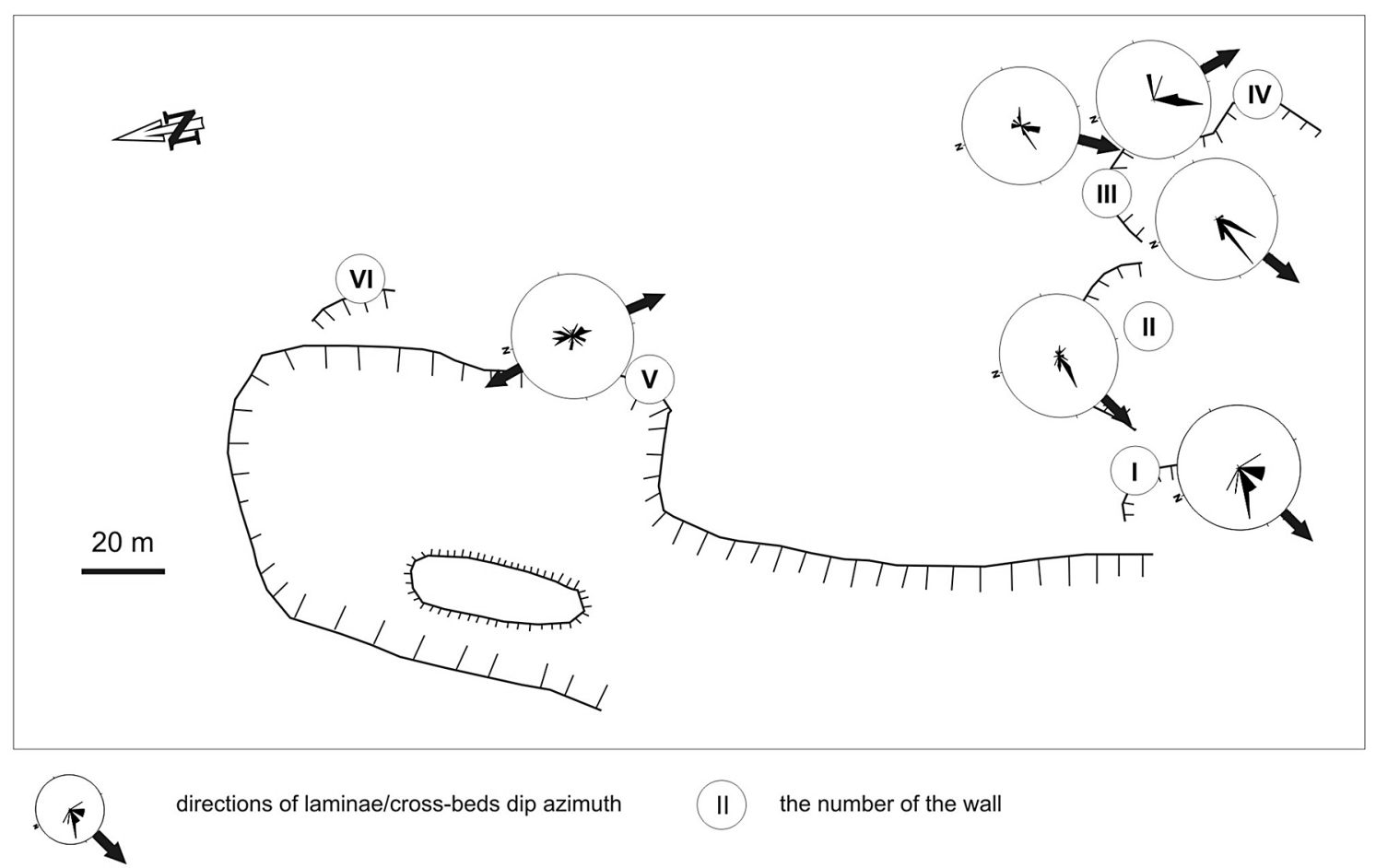

Fig. 8. Overview of the palaeocurrent directions at Niedźwiedziny

need attention in this context are (1) the geomorphology, (2) the sedimentology, and (3) the palaeocurrent directions. A combination of these aspects is required to ascertain whether the deposits at the Niedźwiedziny site reflect sedimentation between the dead-ice bodies or rather an end-moraine hill left during recession of the ice-sheet. In the first case the landform should geomorphologically be considered as a kame, whereas it should be considered as a morainic hill in the second case.

\subsection{Geomorphology}

The Niedźwiedziny pit is situated on the northern slope of the hill (Fig. 9). The differences in altitude between the top of the hill and the surface of the till plain is approx. $15 \mathrm{~m}$. In the south and southeast, the hill ends into a narrow depression. Further to the south, a more level glaciomarginal zone is present. The hill is situated $300 \mathrm{~m}$ in the foreground of the end moraine zone of the Poznan phase of the Weichselian glaciation.

According to the topography, the landform suggests that it is an elongated, irregular kame. It should be mentioned though that end moraines can also form irregular, often fragmented chains of hills.

\subsection{Sedimentology}

The analysis of all lithofacies associations (GC, SAC, SSC, SDC and G) shows that the hill is built mainly of glaciofluvial deposits, with coarsegrained gravels in the lower part and sandy/gravelly deposits in the middle. Deposition took place by currents in a braided-river system. The currents fluctuated strongly with regard to their energy, sediment concentration and aggradation rate. In the initial phase of deglaciation, the sediments were deposited in a gravel-bed channel, which changed its character into a sand-bed channel during the next phase of deglaciation. Decreasing ablation, resulting in a diminishing meltwater discharge was the main factor responsible for this evolution of the glaciofluvial system. The sedimentary deposition thus changed from the proximal, through the middle, to the distal part of a glaciofluvial fan. Channelised currents and sheet-like currents acted alternatively.

The diamicton at the top, representing flowtills, is a direct indicator of an ice-contact environment. Deposition of the diamictic material took place by a relatively small amount of meltwater, most likely in the confined environment of dead-ice blocks, rather than from the massive ice sheet margin. The 


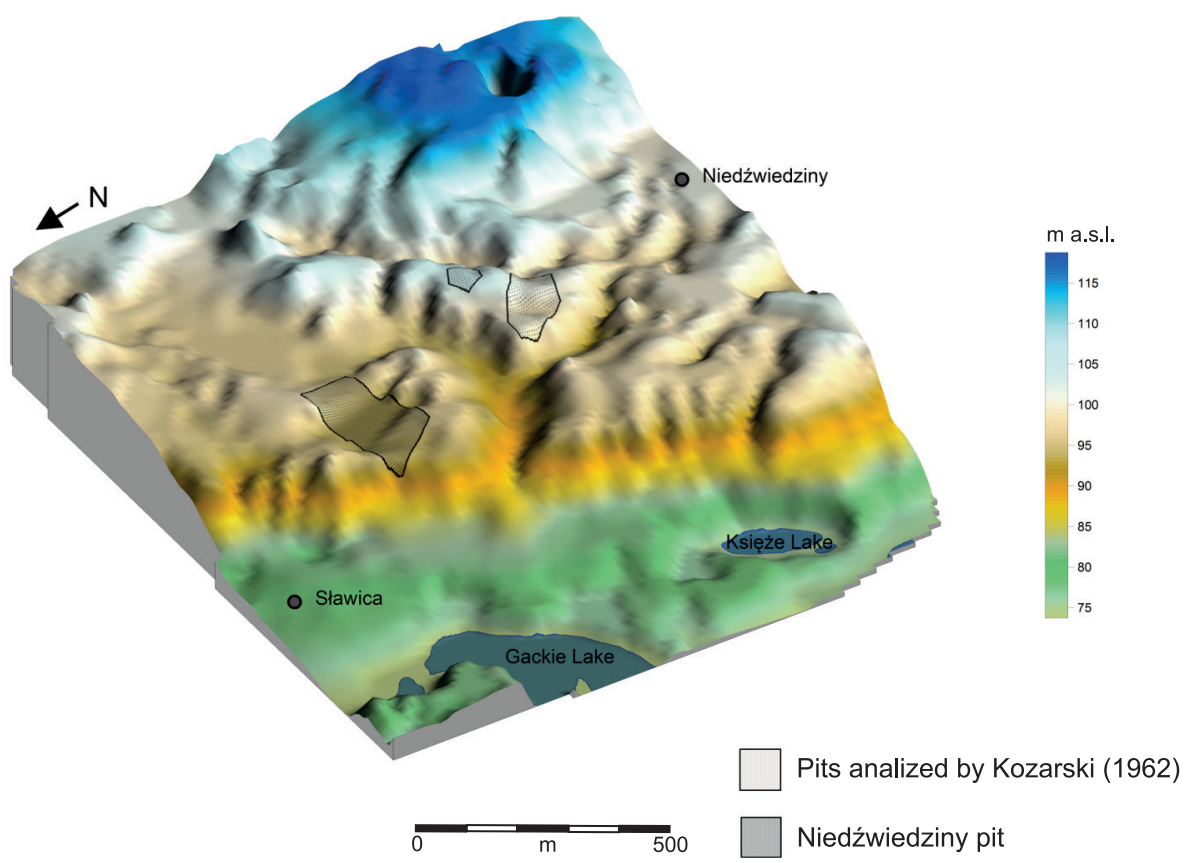

Fig. 9. Morphology of the Niedźwiedziny surroundings as established through the Digital Elevation Model (DEM) diamicton layers have not been washed out. Analogous forms, with non-washed diamictic material atop were reported by Krüger (1994), Marks (1995), Bennett et al. (2000) and Kjaer \& Krüger (2001).

It is worth to point out here that there are no large-scale deformation structures such as faults or folds in the glaciofluvial succession. The lack of glaciotectonic structures excludes an interpretation of the hill as a push moraine; Kozarski (1962), however, interpreted a push moraine origin for a hill located immediately south of the hill under study.

\subsection{Palaeocurrents}

The analysis of palaeocurrent directions provides some insight into the palaeogeographic situation of the study area. The ice sheet masses undoubtedly must have stagnated during deglaciation in an NE-SW oriented depression, which is presently filled with sandur deposits (Figs 1, 9). In the hypothetical situation that the margin of the stagnant ice ran parallel to the depression slope, the meltwater must have flowed out perpendicularly to the ice margin, i.e. towards the SE. In this case the hill must have formed as an end moraine, in which sediments were deposited as a glaciomarginal fan close to the ice margin. (Fig. 10A).

The palaeocurrent analysis shows, however, that the outflow of ablation water around the hill occurred in a different direction than in the hypothetical situation described above. The main ablation outflows took place towards two directions, viz. to the SW and the SSW. Hence, it is assumed

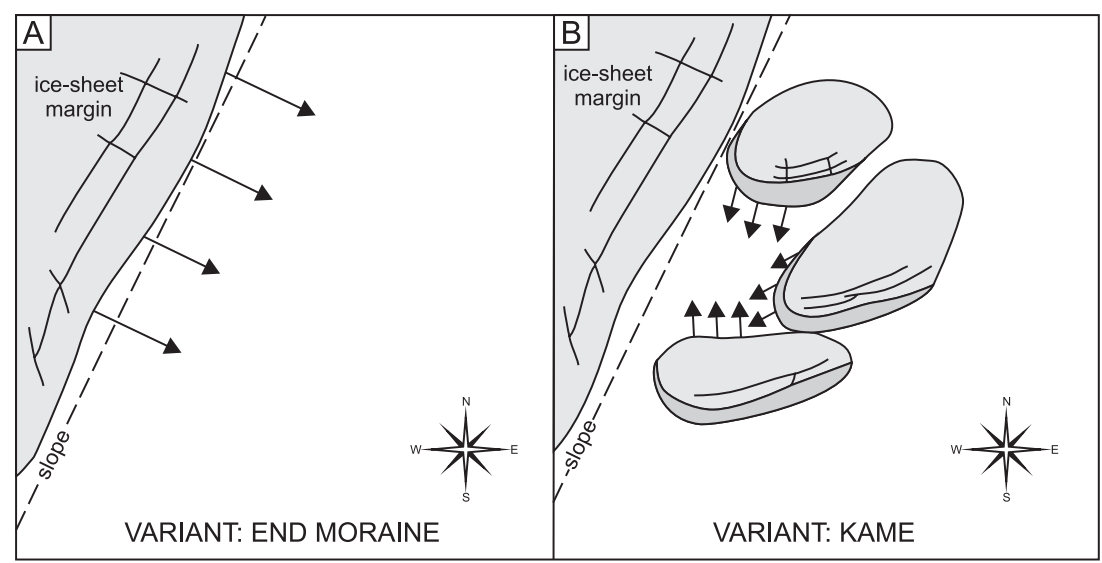

Fig. 10. The two hypothetical models and the meltwater outflow directions. See the text for details 
Fig. 11. Palaeoenvironmental reconstruction of the kame formation at Niedźwiedziny

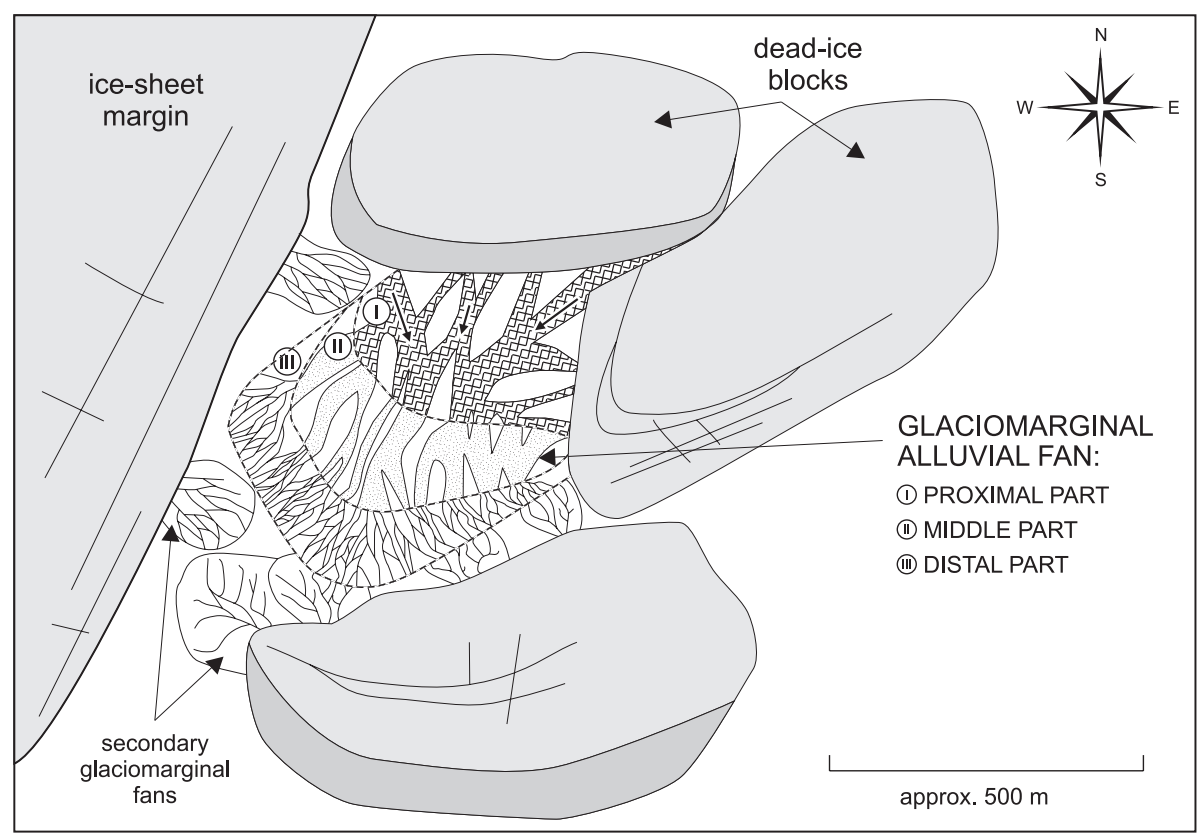

that both the sediment and the meltwater were derived from the other source, i.e. dead-ice bodies located in the north-east, in the depression adjacent to the hill. This would imply that analysed succession has been deposited in interlobate position (Fig. 10B).

\subsection{Palaeogeography of the study area}

All glaciogenic landforms in the Niedźwiedziny area were formed during the retreat of the ice-sheet of the Poznan phase. Some chains of end-moraine ridges originated in the beginning of the deglaciation. They are located north and north-east of Niedźwiedziny (Fig. 9). Kozarski (1962) interpreted the nearby hills with deformed glaciofluvial successions as push moraines, but this is unlikely because of the following. Narrow, elongated depressions that border the morainic ridges in the NW and SW record main meltwater outflows. During the formation of an end moraine, the ice-sheet margin was oriented NE-SW and stagnated about 300 m east of the exposure under study. During the next phase of deglaciation, the ice-margin retreated to the NW and some irregular dead-ice blocks became separated from the active ice sheet. They were located east and south-east of the Niedźwiedziny site, in the bordering depression.

The present study suggests that the Niedźwiedziny hill represents a kame built of glaciofluvial sediments (Figs 10B, 11). It was bordered in the E and SE by blocks of dead-ice, whereas it was connected with the parent ice sheet in the west. An interlobate zone between the dead-ice blocks and the ice sheet developed, where glaciofluvial sedimentation took place. A sandy/gravelly glaciomarginal fan developed with a slope towards the SW. Deposition was irregular, as it was controlled by significant changes in the ablation rate. Subcritical and subcritical/supercritical transitional currents dominated, ranging from deep-channel currents to shallow sheet-like currents. In the final phase of kame development, flowtills were deposited. The cohesive mass flows form a silty-to-sandy diamictic succession.

The above findings differ considerably from previous ones. Kozarski (1962) conducted his studies in now abandoned excavations which were located about $600 \mathrm{~m}$ further to the south-east from the present-day pit. In the author's opinion, the end moraines in the SE reflect an initial phase of deglaciation, whereas the studied kame hill was formed later, when the decaying ice sheet was divided into several dead-ice blocks.

\section{Conclusions}

The following conclusions can be drawn on the basis of the above analyses.

(1) The hill at Niedźwiedziny is located within the marginal zone of Pleistocene (Weichselian) ice sheet, as also indicated by geological and geomorphological maps.

(2) Two main types of the deposits can be distinguished: (a) glaciofluvial deposit; these form 
the lower gravelly channel association (GC) and the thick sandy/gravelly associations (SAC, SSC and SDC) which were deposited by currents with different energy levels; (b) a glacial deposit $(G)$, represented by flowtills representing cohesive mass flows.

(3) During the initial phase of the deglaciation, sedimentation took place in a high-energy, gravelly braided river on the proximal part of an alluvial fan; during the successive diminishing ablation, it acted as a lower-energy fluvial system (sandy/gravelly sediments), on presumably the middle and distal parts of the glaciofluvial fan. In secondary channels and in the lateral parts of the main channel, shallow sheet-like currents dominated. Finally, flowtills were deposited.

(4) The vertical changes of sediment types, from coarse-grained gravelly material in the bottom part, through sandy/gravelly sediments in the main (middle) part and diamictons in the top part indicate that deposition took place by diminishing amount of meltwaters, which reflects slower deglaciation of the ice sheet.

(5) The palaeocurrent data around the hill indicate that the main outflow was oriented toward two directions: SW and SSW. The meltwater was derived from dead-ice blocks in front of the ice-margin, in a narrow depression.

(6) Combination of the sedimentological and geomorphological analyses leads to the conclusion that the hill at Niedźwiedziny is most likely a kame built of glaciofluvial sediments.

(7) The previous interpretation of the hill as a push moraine by Kozarski (1962) concerned deposits about $600 \mathrm{~m}$ to the south-east from the present-day pit. They are located in a distinct chain of hills, reflecting the line of an ice margin. Earlier interpretations of this landform as an end moraine, presented on geomorphological (Krygowski, 1953-1961) and geological (Makowska, 1983) maps seem inappropriate. In the light of the present study, the hill at Niedźwiedziny should be considered as a kame.

(8) The initial stage of deglaciation, i.e. ablation of the ice front, which is usually characterised by the formation of end-moraines passed into areal deglaciation, characterised by the formation of kames.

\section{Acknowledgements}

I want to express my thanks to both anonymous reviewers. The KRUSZGEO Wielkopolskie Kopalnie Company and the Management of the Niedźwiedziny gravel pit are thanked for providing access to the exposure.

\section{References}

Alexander, J., Bridge, J.S., Cheel, R.J. \& Leclair, S.F., 2001. Bed forms and associated sedimentary structures formed under supercritical water flows over aggrading sand beds. Sedimentology 48, 133-152.

Bennett, M.R., Huddart, D., Glasser, N.F. \& Hambrey, M.J., 2000. Resedimentation of debris on an ice-cored lateral moraine in the high-Arctic (Kongsvegen, Svalbard). Geomorphology 35, 21-40.

Cant D.J. \& Walker R.G., 1978. Fluvial processes and facies sequences in the sandy braided South Saskatchewan River, Canada. Sedimentology 25, 625-648.

Cowan, E.J., 1991. The large-scale architecture of the fluvial Westwater Canyon Member, Morrison Formation (Jurassic), San Juan Basin, New-Mexico. [In:] A.D Miall \& N. Tyler (Eds): The three-dimensional facies architecture of terrigenous clastic sediments, and its implications for hydrocarbon discovery and recovery. Society of Economic Paleontologist and Mineralogists Concepts in Sedimentology \& Paleontology 3, 80-93.

Ewert-Krzemieniewska, A., 2010. Sedymentologia osadów plejstoceńskich w Niedźwiedzinach k/Skoków [Sedimentology of the Pleistocene deposits in Niedźwiedziny, near Skoki (eastern Great Polish Lowland)]. M.Sc. thesis Adam Mickiewicz University, Poznań, 90 pp.

Fielding, C.R. \& Webb, J.A., 1996. Facies and cyclicity of the Late Permian Bainmedart Coal Measures in the N Prince Charles Mts, MacRobertson Land, Antarctica. Sedimentology 43, 295-322.

Fredsoe, J., 1982. Shape and dimensions of stationary dunes in rivers. Journal of the Hydraulical Divsion. American Society of Civil Engineers 108, 932-947.

Gruszka, B., Morawski, W. \& Zieliński, T., 2012. Sedimentary record of a Pleistocene ice-sheet interlobate zone (NE Poland). Geologos 18, 65-81.

Hjellbakk, A., 1997. Facies and fluvial architecture of a high-energy braided river: the Upper Proterozoic Seglodden Member, Varanger Peninsula, N Norway. Sedimentary Geology 114, 131-161.

Jones, S.J., Frostick, L.E. \& Astin, T.R., 2001. Braided stream and flood plain architecture: the Rio Vero Formation, Spanish Pyrenees. Sedimentary Geology 139, 229-260.

Kjaer, K.H. \& Krüger, J., 2001. The final phase of deadice moraine development: processes and sediment architecture, Kotlujokull, Iceland. Sedimentology 48, 935-952.

Kozarski, S., 1962. Recesja ostatniego lądolodu z północnej części Wysoczyzny Gnieźnieńskiej a kształtowanie się pradoliny Noteci - Warty [Recession of the last ice sheet from the northern Gniezno Upland and Noteć-Warta glacial valley formation]. Geografia Zeszyty UAM 2(3), 1-154.

Krüger, J., 1994. Glacial processes, sediments, landforms, and stratigraphy in the terminus region of Myrdalsjökull, Iceland. Folia Geographica Danica 21, 1-233.

Krygowski, B. et al., 1953-1961. Mapa geomorfologiczna Niziny Wielkopolskiej, 1:100,000 [Geomorphological 
map of the Great Polish Lowland, scale 1:100,000]. Transcript UAM, Poznań, sheet Rogoźno.

Makowska, A., 1983. Mapa geologiczna Polski, 1:200,000, wersja A - mapa utworów powierzchniowych, Arkusz Gniezno [Geological map of Poland, scale 1:200,000, version A - surface deposits map, sheet Gniezno]. PIG, Warszawa.

Marks, L., 1995. Till facies in the outer end moraine zone of the Wisła Glaciation, NE Poland. [In:] J. Ehlers, S. Kozarski \& P.L. Gibbard (Eds): Glacial deposits in north-central Europe. Balkema, Rotterdam, 309-317.

Marren, P.M., 2001. Sedimentology of proglacial rivers in E Scotland during the Late Devensian. Transactions of the Royal Society of Edinburgh, Earth Sciences 92, 149171.

Miall, A.D., 1977. A review of the braided-river depositional environment. Earth-Science Reviews 13, 1-62.

Miall, A.D., 1996. The geology of fluvial deposits - sedimentary facies, basin analysis, and petroleum geology. Springer, Berlin, $582 \mathrm{pp}$.

Ruszczyńska-Szenajch, H., 1998. Struktura glin lodowcowych jako istotny wskaźnik ich genezy [Till structure as an import ant indicator of their origin]. [In:] E. Mycielska-Dowgiałło (Ed.): Struktury sedymentacyjne i postsedymentacyjne w osadach czwartorzędowych $i$ ich wartość interpretacyjna [Sedimentary and postsedimentary structures of Quaternary deposits and their interpretation]. Warsaw University, Warszawa, 195-243.

Salamon, T. \& Zieliński, T., 2010. Unusual development of a sandur sedimentary succession, an example from the Pleistocene of S Poland. Geologos 16, 83-99.

Santos, M.L. \& Stevaux, J.C., 2000. Facies and architectural analysis of channel sandy macroforms in the upper Parana river. Quaternary International 72, 87-94.

Sarala, P., Johansson, P. \& Valkama, J., 2009. End moraine stratigraphy and formation in the southwestern Pyhä-Luosto fell area, northern Finland. Quaternary International 207, 42-49.

Saunderson, H.C., 1981. Tunnel transformation of antidunes. Physical Geography 2, 125-145.
Singh, A. \& Bhardwaj, B.D., 1991. Fluvial facies model of the Ganga River sediment, India. Sedimentary Geology 72, 135-146.

Sohn, Y.K., 1997. On traction-carpet sedimentation. Journal of Sedimentary Research 67, 502-509.

Sydow, S., 2004. Objaśnienia do szczegótowej mapy geologicznej Polski, 1:50,000, arkusz Murowana Goślina [Explanations to the detailed geological map of Poland, scale 1:50,000, sheet Murowana Goślina]. Państwowy Instytut Geologiczny, Warszawa, $26 \mathrm{pp}$.

Therrien, F., 2006. Depositional environments and fluvial system changes in the dinosaur-bearing Sanpetru Fm. (Late Cretaceous, Romania): post-orogenic sedimentation in an active extensional basin. Sedimentary Geology 192, 183-205.

Thomas, G.S.P. \& Chiverrell, R.C., 2007. Structural and depositional evidence for repeated ice-marginal oscillation along the eastern margin of the Late Devensian Irish Sea Ice Stream. Quaternary Science Reviews 26, 2375-2405.

Todd, S.P., 1989. Stream-driven, high-density gravely traction carpets: possible deposits in the Trabeg Conglomerate Formation, SW Ireland and some theoretical considerations of their origin. Sedimentology 36, 513-530.

Zieliński, T., 1992. Moreny czołowe Polski północno-wschodniej - osady i warunki sedymentacji [End moraines of NE Poland - deposits and sedimentary conditions]. Prace Naukowe Uniwersytetu Ślaskiego (Katowice) 1325, $96 \mathrm{pp}$.

Zieliński, T. \& Pisarska-Jamroży, M., 2012. Jakie cechy litologiczne warto kodować, a jakie nie? [Which features of deposits should be included in the code and which not?]. Przeglad Geologiczny 60, 387-397.

Manuscript received: 20 April 2014 Revision accepted: 25 August 2014 